МОДЕЛЬ СОЦІАЛЬНО-ПЕДАГОГІЧНОЇ КОРЕКЦІї ЕЙДЖИЗМУ

СТУДЕНТСЬКОї МОЛОДІ В ОСВІТНЬО-КУЛЬТУРНОМУ СЕРЕДОВИЩІ ЗАКЛАДУ ВИЩОЇ ОСВІТИ

\title{
AGEISM SOCIAL-PEDAGOGICAL CORRECTION MODEL OF STUDENT YOUTH IN THE EDUCATIONAL AND CULTURAL ENVIRONMENT OF HIGHER EDUCATIONAL ESTABLISHMENT
}

Статтю присвячено пошуку шляхів корекції ейджизму серед студентської молоді. У сучасних сочіокультурних умовах стрімко зростає та набуває широкого розповсюдження явище ейджизму - негативного стереотипного ставлення молоді, зокрема студентської, до представників похилого віку, тому потрібною є педагогічна корекція із залученням виховного потенціалу суспільства, оскільки від успішної сочіалізації студентів у найближчій перспективі залежатиме майбутнє нашої держави. Виникає необхіність моделювання процесу соціально-педагогічної корекції ейджизму студентської молоді в освітньо-культурному середовищі закладу вищої освіти. Висвітлено основні компоненти структурно-срункціональної моделі соціально-педагогічної корекції ейджизму в студентської молоді, зокрема суб'єкт-об'єктний (об'єкт - студенти з високим рівнем прояву ейджизму, а суб'єкти - соціальний педагог, куратори, викладачі, представники студентського самоврядування, громадських організачій культурно-дозвіллєвих закладів тощо), функціонально-цільовий (мета - підвищення едективності корекції ейджизму студент ської молоді через освітньо-культурне середовище 3ВО, фрункції корекції (виправна, компенсувальна, стимулювальна), принципи корекційної діяльності (як загальні, так і спеиіальні)), середовищний (внутрішнє середовище $3 В О$ його складники (організачійно технологічний, навчально-профессійний, соціально-виховний) та зовнішнє (територіальні чентри соціального обслуговування соціальні служби, громадські організації, державні заклади, будинки престарілих, благодійні організації, геріатричні пансіонати для ветеранів праці, клуби активного довголіття громадян похилого віку, заклади культури, університети третього віку та віртуальний простір тощо), змістовно-технологічний (підготовчий, основний, підсумковий етапи, зміст, напрями, орорми та методи) та результативний (критерії, показники й рівні очінювання та очікуваний результат - зниження високого рівня ейджизму серед студентської молоді). Виділено специфіку моделі в умовах освітньо-культурного середовища закладу вищої освіти. Особлива увага приділяється єдності внутрішнього та зовнішнього соціально-виховного середовищ ЗВО в процесі соціально-педагогічної корекції ейджизму студентської молоді.

Ключові слова: структурно-фрункціональна модель, ейджизм, студентська молодь, соціально-педагогічна корекція, освітньо-культурне середовище закладу вищої освіти.

Статья посвящена поиску путей коррекции эйджизма среди студенческой молодежи. В современных социокультурных условиях стремительно растет и получает широкое распространение явление эйджизма - негативного стереотипного отношения молодежи, в частности студенческой, к представителям пожилого возраста, поэтому нужна педагогическая коррекция с привлечением воспитательного потенциала общества, поскольку от успешной социализации студентов в ближайшей перспективе будет зависеть будущее нашей государства. Воз- никает необходимость моделирования прочесса социально-педагогической коррекции эйджизма студенческой молодежи в образовательно-культурной среде учреждения высшего образования Освещены основные компоненты структурно-фрункциональной модели социально-педагогической коррекции эйджизма в студенческой молодежи, в частности субъект-объектный (объект - студенты с высоким уровнем про явления эйджизма, а субъекты - социальный педагог, кураторы, преподаватели, представители студенческого самоуправления, общественных организаций культурно-досуговых учреждений и т.д.) функционально-целевой (цель - повышение эфрфективности коррекции ейджизму студенческой молодежи через образовательнокультурную среду ЗВО, функции коррекции (исправительная, компенсирующая, стимулирующая), принципы коррекционной деятельности (как общие, так и специальные)), компонент среды (внутренняя среда ЗВ О и его составляющие (организационно-технологический, учебно-профрессиональный, социально-воспитательный) и внешняя (территориальные центры социального обслуживания, социальные службы, общественные организации, государственные учреждения, дома престарелых, благотворительные организации, гериатрические пансионаты для ветеранов труда, клубы активного долголетия пожильх граждан, учреждения культуры, университеты третьего возраста и виртуальное простран ство и т.д.) содержательно-технологический (этапы: подготовительный, основной, результативный; содержание, направления, формы и методы) и результативный (критерии, показатели и уровни оценки и ожидаемый результат - снижение высокого уровня эйджизма среди студенческой молодежи). Выделена специфика модели в условиях образовательно-культурной среды учреждения высшего образования. Особое внимание уделяется единству внутреннего и внешнего социально-воспитательных сред ЗВО в процессе социально-педагогической коррекции эйджизма студенческой молодежи.

Ключевые слова: структурно-фуннкцио нальная модель, эйджизм, студенческая молодежь, социально-педагогическая коррекция, образовательно-культурная среда учреждения высшего образования.

In modern socio-cultural conditions, phenomenon of ageism is widespread and growing rapidly and it receives the negative stereotyped attitude of young people, in particular students, to the elderly representatives, therefore, it is necessary to find the effective ways of this phenomenon correction, as the future of our state will depend on the successful socialization of students. Thus, there is a need to model the process of sociopedagogical correction of students' ageism in the educational and cultural environment of a higher educational establishment. The article describes the essence of "sociopedagogical correction of student's youth". It has been determined the main components of structural and functional model of sociopedagogical correction of ageism in student 
УдК 378.035:316.647.82-057.087 DOI https://doi.org/10.32843/26636085.2019.12-1.27

\section{Печериця Н.М.}

аспірант кафедри соціальної педагогіки Харківської державної академії культури youth: subject-object (object of correctional activity are the students with a high level of ageism manifestation, and subject - is a social teacher, tutors, lectors, student self-government representatives, representatives of public, state organizations, cultural establishments, etc.); functional-objective (reflects the functions of social-pedagogical activity in relation to correction (corrective, stimulating and compensatory), the aim which essence is to increase the efficiency of students' ageism correction through the educational and cultural environment of the by mass-media means of social and pedagogical activities, principles of corrective action, as general and special); environmental (represents the structure of educational and cultural environment of massmedia, which is divided into the following components: organizational - technological, training-vocational, social-educational); content- technological (outlines the content and stages: preparatory, coordination, implementation in correlation which corresponds to the forms, directions, methods of social and pedagogical activities in relation to correction in the appropriate interaction at the internal and external levels); Effective (represents the criteria, indicators and levels of evaluation and the expected result). It has been determined the specificity of model in conditions of the educational and cultural environment of higher educational establishment. It has been paid the particular attention to the unity of the internal and external social and educational environments in course of ageism correction of student youth. Key words: structural-functional model, ageism, student youth, socio-pedagogical correction, educational-cultural environment of higher educational establishments.
Постановка проблеми у загальному вигляді. В умовах бурхливого розвитку інфрормаційного суспільства набуває актуальності дослідження процесу позитивного соціального розвитку студентської молоді, оскільки від гармонійності соціалізації представників цієї вікової групи залежить перспектива розвитку нашої держави в майбутньому. Нові соціокультурні умови існування спричинили те, що сьогодні студентська молодь $€$ найактивнішим та наймайстернішим користувачем сучасних інорормаційно-комунікативних технологій (далі - IKT), тому останні $є$ основним засобом соціального розвитку, а Інтернет - середовищем соціалізації, що носить не лише позитивний, але й негативний характер, оскільки надмірний та стихійний вплив комп'ютерних технологій і постійне занурення у віртуальний простір деструктивно впливає на процес соціального становлення студентів, подекуди призводить до поширення в молодіжній субкультурі інфрантилізму, споживацького ставлення до суспільного життя, знедуховлення, соціальної безвідповідальності, нігілізму, пасивності, агресивності, вседозволеності, нетерпимості, критиканства, знецінення думок інших, зокрема до ейджизму. У сучасних соціокультурних умовах виникає актуальна необхідність пошуку та реалізації ефективних шляхів подолання ейджизму серед студентської молоді, одним із яких $є$ моделювання процесу соціально-педагогічної корекції та його реалізація в освітньо-культурному середовищі закладу вищої освіти (далі - ЗВО), що сприятиме гармонізації не тільки особистісного, а й профресійного розвитку, успішній соціалізації студентської молоді, іï інтеграції в соціумі.

Аналіз останніх досліджень і публікацій. Різні аспекти фрормування та розвитку студентської молоді досліджували Т. Артемонова, Н. Богданова, О. Білик, І. Курліщук, В. Лісовський, Н. Максимовська, М. Максимовський, А. Рижанова, О. Рудакова, С. Савченко, О. Севастьянова, Л. Сукорянська, В. Штифрурак, О. Язловецька та інші. Явище ейджизму вивчали Р. Батлер, О. Березіна, В. Біскуп, М. Євдокимова, Т. Горо- дова, О. Колпіна, О. Краснов, І. Кресіна, Л. Магдисюк, А. Мікляєва, Л. Міщиха та інші; освітньокультурне середовище - О. Білик, Д. Порох, О. Прищепа, В. Стрельцова та інші; проблему соціально-педагогічної корекції різних негативних соціальних явищ - Г. Василенко, Т. Гніда, Н. Заверико, В. Носенко, Т. Окушко, Н. Сейко, Г. Товканець та інші.

Виділення невирішених раніше частин загальної проблеми. Проблему соціально-педагогічної корекції ейджизму студентської молоді досліджено ще не достатньо, зокрема відсутня науково обґрунтована модель підвищення ефективності соціально-педагогічної корекції ейджизму в освітньо-культурному середовищі ЗВО.

Метою статті $€$ теоретичне обґрунтування структурно-фуункціональної моделі соціально-педагогічної корекції ейджизму студентської молоді в освітньо-культурному середовищі 3ВО.

Виклад основного матеріалу. Старіння населення планети, транссрормація традиційних ціннісних орієнтацій, зниження виховної ролі інституту сім'ї, орієнтування інорормаційної культури світу на все нове призводить до зміни ставлення стосовно людей похилого віку та поширення ейджизму. Ейджизм $€$ негативним явищем сучасності, що пов'язано зі зростанням значущості молодого покоління, особливо студентів, в інформаційному просторі. За статистичними даними на 2017 р., 97\% молоді (віком від 15 до 29 років) є активними користувачами IKT, представники віком від 55 до 64 років становлять $38 \%$, а люди старше 65 років лише 12\% [2]. Студентська молодь через недостатність соціального досвіду та сорормованості ціннісних орієнтацій піддається впливу стереотипізованих знань про людей похилого віку через засоби масової інсрормації, що призводить до знецінення, заперечення соціального досвіду минулих років, зменшення значущості людей похилого віку в інорормаційному суспільстві та поширення ейджизму. Беручи за основу обґрунтоване визначення ейджизму Р. Батлера [4, с. 243-246] та спираючись на дослідження В. Біскупа, О. Березіної, 
М. Єкімової, М. Житинської, Н. Клименюк, І. Кресіної, К. Познанської, А. Мікляєвої, Е. Палмора, Н. Смелзер та інших, ейджизм розглядаємо як негативний соціальний стереотип, що презентує «перекручені», спрощені знання про старість та людей похилого віку, які закарбовуються в індивідуальній та суспільній свідомості, що надалі спричиняє дискримінаційні дії до цієї вікової категорії на рівні міжособистісного спілкування та різних соціальних інститутів. Саме тому актуалізується необхідність пошуку та реалізації в сучасних реаліях еорективних шляхів подолання ейджизму серед студентської молоді.

Теоретико-методологічною базою у розробленні структурно-фрункціональної моделі соціально-педагогічної корекції ейджизму студентської молоді в освітньо-культурному середовищі ЗВО є праці Б. Ананьєва, А. Алексюк, К. Астахової, Н. Максимовської, М. Максимовського, А. Рижанової, О. Рудакової, С. Савченка, С. Харченка, Л. Сукорянської, В. Штифрурак та інших, котрі досліджували аспекти соціального розвитку студентської молоді; Р. Батлера, О. Березіної, В. Біскупа, М. Євдокимової, І. Кресіної, Л. Магдисюк, А. Мікляєвої та інших, що вивчали феномен ейджизму; О. Білик, Д. Порох, О. Прищепи, В. Стрельцова та інших, що розглядали особливості освітньо-культурного середовища. Науково-методичні засади профрілактично-корекційної роботи вивчали Б. Алмазов, С. Бєличева, І. Дубровіна, А. Капська, Ю. Клейберг, І. Козубовська, А. Макаренко, В. Оржеховська, В. Татенко, Т. Титаренко, С. Шацький, Л. Шнейдер та інші. Питання теоретичного обґрунтування корекційної діяльності соціального педагога досліджували Є. Бондаревська, В. Бочарова, Б. Вульфов, І. Литвинов, А. Мудрик, Л. Семенюк, А. Тарасов та інші. Проблему соціально-педагогічної корекції різних негативних соціальних явищ розглядали Г. Василенко, Т. Гніда, Н. Заверико, В. Носенко, Т. Окушко, Н. Сейко, Г. Товканець та інші.

Структурно-фрункціональна модель соціальнопедагогічної корекції ейджизму студентської молоді в освітньо-культурному середовищі ЗВО характеризується єдністю таких структурних компонентів: суб'єкт-об'єктного, фрункціонально-цільового, середовищного, змістовно-технологічного та результативного.

Суб'єкт-об'єктний компонент представлений об'єктами корекції, зрозуміло, що ними є студенти з високим рівнем ейджизму, провідним суб'єктом $€$ соціальний педагог, а потенційними - куратори, викладачі, представники студентського самоврядування, громадських організацій, державних закладів тощо. Слід зазначити, що провідним та найбільш оптимальним суб'єктом для здійснення соціально-педагогічної корекції ейджизму в студентської молоді в освітньо-культурному середовищі 3ВО є саме соціальний педагог. Він $€$ спеціалістом у сорері соціального виховання та здатний із найбільшою ефективністю інтегрувати та координувати соціально-педагогічну діяльність щодо корекції ейджизму в студентів, об'єднувати зусилля фрахівців зовнішнього соціокультурного середовища та стимулювати самовиховні можливості студентів. Діяльність соціального педагога у ЗВО сприятиме створенню оптимальних умов успішного соціального розвитку та ефективної інтеграції студентської молоді в соціум, зберігаючи толерантні міжпоколінні стосунки. Соціальний педагог сприяє регулюванню всіх виховних впливів (тобто посиленню позитивних та нейтралізації негативних на розвиток соціальності студентської молоді), координує діяльність і взаємодію всіх соціально-виховних суб'єктів як на внутрішньому, так і на зовнішньому рівнях середовища, допомагає налагодженню позитивної міжпоколінної взаємодії, сприяє залученню різноманітних соціальних інституцій для корекції ейджизму в студентів та стимулює потенційні можливості останніх щодо самокорекції поведінки та ставлення до представників похилого віку. Як правило, посади соціальних педагогів у більшості ЗВО відсутні, але в деяких ЗВО все-таки наявні, тому сподіваємося, що європейська інтеграція нашої країни забезпечить їх обов'язкове введення у всіх 3ВО. До потенційних суб'єктів соціально-педагогічної корекції ейджизму студентів у ЗВО зараховуємо кураторів, викладачів гуманітарних дисциплін, зокрема педагогічних, представників студентського самоврядування, громадських організацій, державних закладів, із якими має проводитися відповідна підготовка, щоб вони стали реальними суб'єктами.

Метою структурно-орункціональної моделі соціально-педагогічної корекції ейджизму $є$ підвищення ефрективності соціально-педагогічної корекції ейджизму студентської молоді в освітньо-культурному середовищі ЗВО. До фрункцій соціально-педагогічної корекції зараховуємо: виправну (передбачає зміну негативного стереотипного сприйняття людей похилого віку), компенсувальну (посилення тих позитивних якостей чи діяльності студента, які сприятимуть зміні ставлення до людей похилого віку), стимулювальну (спрямовану на заохочення зміни негативного стереотипного сприйняття людей похилого віку, активізації позитивних якостей, ціннісних орієнтацій, установок у студентської молоді, прагнення до суспільно-корисної діяльності). До загальних принципів належать такі: цілеспрямованості, цілісності, системності, гуманності, толерантності, врахування індивідуальних та вікових особливостей студентів, а також діяльнісний. Розкриємо більш детально специфрічні принципи соціально-педагогічної корекції: єдності діагностики та корекції (забезпечує цілісність та правильність корекційної- 
педагогічного процесу), комплексності корекційних методів та прийомів (застосування сукупності форм, методів, засобів, прийомів, способів, що забезпечать максимально ефективний корекційний вплив), інтеграції соціальних інституцій (взаємодія та координація внутрішнього та зовнішнього середовищ для досягнення поставленої мети), стимулювання та мотивації (сприяє мотивації позитивного ставлення студентів до представників похилого віку), самокорекції (усвідомлення необхідності подолання стереотипного ставлення до людей похилого віку та самозміни) тощо.

Важливим для підвищення ефрективності соціально-педагогічної корекції (далі - СПК) ейджизму в ЗВО є середовищний компонент, оскільки він відбиває особливості СПК та структуру освітньокультурного середовища 3ВО. О. Білик [1, с. 247] у дослідженні стосовно соціалізації іноземних студентів у освітньо-культурному середовищі ЗВО ґрунтовно розкрито складники внутрішнього середовища $3 В 0$ (організаційно-технологічний, навчально-професійний, соціально-виховний). Оскільки освітньо-виховний процес у ЗВО єдиний та вікові характеристики студентської молоді збігаються, то будемо керуватися ними під час соціально-педагогічної корекції ейджизму в студентів. Спираючись на дослідження О. Білик, Н. Максимовської, М. Максимовського, А. Рижанової, С. Савченко та інших, стверджуємо, що соціальний розвиток особистості відбувається й поза межами середовища 3ВО, тобто у відкритому соціальному просторі міста, регіону, країни тощо. Зазначимо, що в умовах інорормаційного суспільства соціальний розвиток студентської молоді не обмежується лише середовищем 3ВО, а виходить за його межі, тому доцільно в середовищному компоненті виділити й зовнішнє соціально-виховне середовище. Досліджуючи зовнішнє соціокультурне середовище, базуємося на дослідженні А. Мікляєвої, яка, аналізуючи досвід зарубіжних соціальних психологів М. Хуммера, Р. Радоса, вказує на те, що найбільш ефективним напрямом роботи з подолання ейджизму є безпосередні контакти 3 представниками похилого віку [3, с. 160]. Виходячи 3 дійсних соціальних закладів, організацій, установ тощо для людей похилого віку, до реального зовнішнього соціально-виховного середовища зараховуємо взаємодію із соціальними службами, територіальними центрами соціального обслуговування, будинками престарілих, громадськими, благодійними організаціями, геріатричними пансіонатами для ветеранів праці, клубами активного довголіття громадян похилого віку, закладами культури, університетами третього віку, культурно-дозвіллєвими організаціями; до віртуального - інтернеткафе для людей похилого віку, віртуальні клуби, медіа-проекти, веб-сайти, онлайн-навчання тощо. Важливою особливістю є консолідація виховних зусиль як зовнішнього, так і внутрішнього середовищ, що вможливить повноцінну, ефективну соціально-педагогічну корекцію ейджизму в студентів.

У змістовно-технологічному компоненті виділяємо такі етапи: підготовчий, основний, підсумковий. Як було зазначено раніше, І етап стосується підготовки потенційних суб'єктів соціально-педагогічної корекції щодо корекції ейджизму в студентів. Оскільки потенційними суб'єктами у внутрішньому середовищі ЗВО є викладачі гуманітарних дисциплін, зокрема педагогічних, куратори, співпрацівники закладу освіти, то необхідною $€$ підготовка щодо особливостей СПК, щоб зробити їх реальними суб'єктами корекційної діяльності. Провідним завданням змісту підготовки суб'єктів СПК $є$ підвищення та поглиблення компетенції щодо проблеми ейджизму, необхідності її подолання, особливостей соціально-педагогічної корекції та основних фрорм, методів цієї діяльності в сучасному студентському середовищі. Виступ на педагогічній нараді на тему «Явище ейджизму та його наслідки», семінар «Ейджизм стосується кожного..!», консиліум зі соціальними педагогами та фрахівцями соціальної сорери стосовно особливостей СПК ейджизму в освітньокультурному середовищі ЗВО та сучасних ефективних фрормах та методах корекції його явища в студентської молоді - усе це підвищить рівень усвідомленості та вмотивованості педагогів щодо необхідності подальшої діяльності та особливостей СПК ейджизму студентської молоді. Проміжним результатом на цьому етапі $є$ створення соціально-педагогічного корекційно-координаційного центру 3ВО, спрямованого на узгодження та затвердження загального плану соціально-педагогічної корекційної діяльності та взаємодії суб'єктів щодо подолання ейджизму, забезпечення методикою корекційної діяльності тощо. Говорячи про зовнішнє соціокультурне середовище, це дасть можливість визначити соціальні інституції, окреслити зміст, види, напрями та фрорми взаємодії із середовищем ЗВО, скласти спільний план корекційної діяльності під час зустрічей, онлайн-бесід, екскурсій, провести підготовку з представниками зовнішніх інституцій щодо психовікових особливостей студентської молоді за допомогою онлайнбесіди «Сучасні специфічні особливості студентів», фроруму «Соціально-педагогічна корекція ейджизму: провідні напрями, форми» тощо, що сприятимуть осягненню представниками зовнішніх соціальних інституцій особливостей сумісної діяльності щодо корекції ейджизму в студентської молоді. Результатом є набуття суб'єктності суб'єктами СПК.

Основний етап змістовно-технологічного компонента передбачає діяльність за такими трьома напрямами, як консолідація соціально-виховних зусиль внутрішнього середовища, інтеграція соці- 
ально-виховної діяльності зовнішніх соціальних інституцій щодо корекції ейджизму студентів у 3ВО, об'єднання зусиль внутрішнього та зовнішнього соціально-виховних середовищ для корекції ейджизму студентів через активізацію студентського самоврядування та самокорекційного потенціалу студентів у зовнішньому соціокультурному середовищі. У напрямі консолідації соціально-виховних зусиль внутрішнього середовища ЗВО щодо корекції ейджизму необхідно вжити заходів, що сприятимуть об'єднанню суб'єктів корекційної діяльності, а також активізації, мотивації та залученню до співпраці активу студентського самоврядування 3 метою зниженню рівня ейджизму в студентів із високим рівнем прояву цього явища. Під час упровадження соціальнопедагогічної діяльності щодо корекції необхідно враховувати специсріку освітньо-культурного середовища кожного ЗВО. Розглянемо особливості корекційної діяльності у кожному із зазначених складників освітньо-культурного середовища 3ВО. Форми та методи в організаційно-технологічному складнику передбачають створення ціннісного, толерантного життєвого простору, організацію діяльності викладачів та співробітників 3ВО щодо СПК ейджизму, наприклад, за допомогою online-брифрінгу «Ейджизм -найпоширеніший вид дискримінації», лекції-прес-конфреренції у бібліотеці «Наслідки ейджизму», наукових дебатів у гуртожитку «Вікова дискримінація - яка вона?» тощо. У навчально-професійному складнику рекомендовано залучити до співпраці викладачів гуманітарних дисциплін із метою вдосконалення, розробки й упровадження навчально-методичних матеріалів, ураховуючи проблеми ейджизму в студентському середовищі, сприяти фрормуванню позитивних соціальних якостей та ціннісного ставлення у студентів до представників цієї вікової категорії в навчально-виховному процесі та під час виробничої практики. Для того, щоб удосконалити навчальні дисципліни стосовно проблематики ейджизму в нашому суспільстві, необхідно залучитися підтримкою викладачів гуманітарного профрілю. Так, наприклад, дисципліну «Філосоорія», рекомендовано врізноманітнити темою «Єдність і протистояння двох полярних вікових груп», а в дисципліні «Соціологія» тему «Особистість і суспільство» - підтемою «Сучасні соціальні відхилення між віковими групами» тощо. Соціально-виховний складник внутрішнього освітньо-культурного середовища ЗВО спрямований на організацію різноманітних фестивалів, соціокультурних проектів, квестів, соціально-педагогічних акцій, наприклад: «Єдність поколінь», сумісні пізнавально-дозвіллєві фрестивалі «60+», віртуальні фрлешмоби, ярмарки «Діалог між поколіннями», віртуальний клуб «Ці люди заслуговують, що їх знали», мультимедійний проект «Скажемо разом ейджизму ні!», онлайн-розповіді видатних людей похилого віку та волонтерів, перегляд та обговорення кіно-, відеоматеріалів, волонтерську діяльність тощо, що направлені на здобуття об'єктивних та точних знань щодо людей похилого віку, формування соціальної активності у студентів, популяризації позитивних ціннісних орієнтацій щодо людей похилого віку в соціумі та віртуальному просторі, гармонійних, рівноправних та толерантних міжпоколінних взаємовідносин, а також важливим $€$ залучення студентів до взаємодії 3 людьми похилого віку під час проходження ознайомчої, виробничої практики тощо. Проміжним результатом цього напряму є об'єднання та зміцнення соціально-виховних зусиль щодо корекції ейджизму серед студентів у освітньо-культурному середовищі ЗВО на організаційно-технологічному, навчально-профресійному, соціально-виховному рівнях освітньо-виховного простору. Наступний напрям стосується інтеграції соціально-виховної діяльності зовнішніх соціальних інституцій щодо корекції ейджизму студентів у ЗВО. Його необхідність полягає в тому, щоб залучити представників зовнішніх соціальних інституцій безпосередньо до взаємодії зі студентською молоддю на території ЗВО 3 метою ефективного корекційно-виховного впливу щодо проблеми ейджизму. У цьому напрямі доцільним $є$ здійснення виступів представниками територіальних центрів «Особливості адаптації людей похилого віку в сучасному соціумі», представників медичних «АнтиЕйдж», правоохоронних організацій «Законність явища ейджизму та наслідки», міжпоколінних зустрічей «Мудрість в кожного своя», виїзних семінарів «Хоч за 60, але молоді душею» тощо. Результатом цього напряму $€$ інтегрованість соціально-виховних зусиль зовнішніх соціальних інституцій в освітньо-культурне середовище закладу для єдиного, цілісного, гармонійного та успішного фуункціонування 3 метою подолання проблеми ейджизму в сучасних студентів. Останній напрям уміщує необхідність об'єднання зусиль внутрішнього та зовнішнього середовищ для ефективної корекції ейджизму студентів через активізацію студентського самоврядування та їх самокорекційного потенціалу, оскільки основною рисою студентського віку $є$ прагнення до самостійності, а також важливим $є$ сприяння самокорекції ініціатив студентів, які б допомагали фрормуванню активної соціально-позитивної позиції стосовно представників похилого віку. Робота в цьому напрямі здійснюється за допомогою залучення студентської молоді в середовище соціально-виховних інституцій зовнішнього рівня. Наприклад, під час волонтерської діяльності, що $€$ можливою під час організації студентами свят чи заходів у будинках престарілих, територіальних центрах, волонтерської допомоги представникам похилого віку в опануванні IКТ, проведенні 
різноманітних майстер-класів, благодійних акцій зі збору необхідних речей у будинок пристарілих «Частинка твого тепла», ярмарок «Естафрета доброти», організації ретро-вечора для представників похилого віку тощо. Результатом у цьому напрямі $\epsilon$ зміна перебігу безпосередніх контактів із представниками похилого віку негативного стереотипного ставлення на позитивне, поява толерантного ставлення та прагнення студентів до активної суспільно-корисної діяльності, фрормування соціально-позитивної позиції стосовно представників похилого віку та самокорекції студентів.

Останнім елементом моделі $є$ результативний, що передбачає аналіз та моніторинг ефективності корекційної діяльності та внесення відповідних корективів, що вміщує результативний компонент (критерії, показники) та традиційні рівні (високий, середній, низький) прояву ейджизму в студентів. Результатом на цьому етапі $€$ зниження рівня ейджизму в студентської молоді.

Висновки. Поширення негативного соціального явища ейджизму серед студентів підтверджує актуальність розробки структурно-срункціональної моделі для підвищення ефективності соціально-педагогічної корекції ейджизму студентської молоді в освітньо-культурному середовищі 3ВО. У презентовану структурно-функціональну модель соціально-педагогічної корекції ейджизму покладено такі структурні компоненти: суб'єктнооб'єктний, фрункціонально-цільовий, середовищний, змістовно-технологічний та результативний. Корекційна діяльність здійснюється на двох рівнях ЗВО, зокрема внутрішньому та зовнішньому, що сприятиме зміні негативного соціального стереотипу в студентів щодо людей похилого віку, гармонізації, рівноправності міжпоколінних взаємовідносин. Внутрішнє середовище ЗВО сприяє виправленню та зміні негативного ставлення студентів на ціннісне й толерантне до представників похилого віку, а зовнішнє - стимулює позитивні зміни у ставленні студентів до людей похилого віку, сприяє розвитку мотивації на соціально-схвалені способи та види взаємодії з цими людьми. Для корекційної діяльності обрано як традиційні, так й інноваційні методи, засоби, форми, які спрямовані на витіснення негативного стереотипу сприйняття людей похилого віку та зміну негативного стереотипу на толерантне ставлення за допомогою мотивування, компенсації, залучення до спільної діяльності, взаємодії, набуття об'єктами процесу корекції нових соціальних якостей, знань, ціннісного ставлення до людей похилого віку, опанування досвідом позитивного спілкування та взаємодії 3 ними. Перспективою подальшого дослідження $є$ розробка програми соціально-педагогічної корекції ейджизму студентської молоді в освітньо-культурному середовищі, враховуючи специсріку відповідних закладів вищої освіти.

\section{БІБЛІОГРАФІЧНИЙ СПИСОК:}

1. Білик О.М. Теорія та методика соціалізації іноземних студентів в освітньо-культурному середовищі вищого навчального закладу: дис. ... докт. пед. наук: 13.00.05; Д3 «Луганський нац. ун-т ім. Т. Шевченка». Старобільськ, 2018. 683 с.

2. В Украине на начало 2017 насчитано 21,6 млн пользователей интернета. Медиа-новости. 2017. URL: https://promo.semantrum.net/ru/2017/04/21/vukraine-na-nachalo-2017-naschitano-21-6-mlnpolzovatelej-interneta/.

3. Микляева А.В. Методы исследования эйджизма: зарубежный опыт. URL: https://cyberleninka.ru/article/n/metody-issledovaniyaeydzhizma-zarubezhnyy-opyt.

4. Butler R.N. Age-ism: Another form of bigotry. The Gerontologist. 1969. Vol. 9. P. 243-246. 